\title{
Blockade of LIGHT/LT $\beta$ and CD40 signaling induces allospecific $T$ cell anergy, preventing graft-versus-host disease
}

\author{
Koji Tamada, ${ }^{1}$ Hideto Tamura, ${ }^{1}$ Dallas Flies, ${ }^{1}$ Yang-Xin Fu, ${ }^{2}$ Esteban Celis, ${ }^{1}$ \\ Larry R. Pease, ${ }^{1}$ Bruce R. Blazar, ${ }^{3}$ and Lieping Chen ${ }^{1}$ \\ ${ }^{1}$ Department of Immunology, Mayo Clinic, Rochester, Minnesota, USA \\ ${ }^{2}$ Department of Pathology, University of Chicago, Chicago, Illinois, USA \\ ${ }^{3}$ Cancer Center and Department of Pediatrics, Division of Bone Marrow Transplantation, University of Minnesota, \\ Minneapolis, Minnesota, USA
}

Address correspondence to: Lieping Chen, Department of Immunology, Mayo Clinic, 200 First Street SW, Rochester, Minnesota 55905, USA.

Phone: (507) 538-0013; Fax: (507) 284-1637; E-mail: chen.lieping@mayo.edu.

Received for publication June 22, 2001, and accepted in revised form December 24, 2001.

Previous studies have shown that blockade of LIGHT, a T cell costimulatory molecule belonging to the TNF superfamily, by soluble lymphotoxin $\beta$ receptor-Ig (LT $\beta \mathrm{R}-\mathrm{Ig}$ ) inhibits the cytotoxic T lymphocyte (CTL) response to host antigenic disparities and ameliorates lethal graft-versus-host disease (GVHD) in a B6 to BDF1 mouse model. Here, we demonstrate that infusion of an mAb against CD40 ligand (CD40L) further increases the efficacy of LT $\beta \mathrm{R}-\mathrm{Ig}$, leading to complete prevention of GVHD. We further demonstrate that alloantigen-specific CTLs become anergic upon rapid expansion, and persist in the tolerized mice as a result of costimulatory blockade. Transfer of anergic CTLs to secondary F1 mice fails to induce GVHD despite the fact that anergic CTLs can be stimulated to proliferate in vitro by antigens and cytokines. Our study provides a potential new approach for the prevention of lethal GVHD.

J. Clin. Invest. 109:549-557 (2002). DOI:10.1172/JCI200213604.

\section{Introduction}

Graft-versus-host disease (GVHD) is caused by orchestrated alloreactive immune responses and is a major complication of bone marrow (BM) transplantation. Although ex vivo depletion of T cells can protect patients from severe GVHD, complications such as graft rejection, leukemia relapse, and delayed immune reconstitution can result from this approach (1). Pharmacological agents with immunosuppressive agents prevail as major therapeutic interventions in current clinical settings, but they require prolonged administration that can result in global immune suppression. It is highly desirable to induce a selective immunological unresponsiveness to host antigens that spares general $\mathrm{T}$ cell immunity against pathogens or residual leukemia cells.

Costimulatory receptor-ligand interactions play a critical role in the priming, growth, activation, differentiation, and death of $\mathrm{T}$ cells (2). Costimulatory blockade by either soluble receptor for or $\mathrm{mAb}$ against ligands has a profound effect and can lead to selective tolerance of $\mathrm{T}$ cells against alloantigens in some cases (3). Manipulations of B7-CD28 costimulatory interaction $(4,5)$ and of pathways belonging to TNF superfamily members such as CD40 and CD40 ligand (CD40L) (6), 4-1BB and 4-1BB ligand (7), OX40 and OX40 ligand (8), and LIGHT-HVEM (9) are capable of ameliorating GVHD to a certain degree and prolonging recipient survival. However, the mechanism accounting for $T$ cell tolerance and the fate of host-reactive $\mathrm{T}$ cells upon costimulatory blockade are less understood.

Our previous studies demonstrated that LIGHT, a member of the TNF superfamily, provides potent costimulatory activity for T cells, enhancing proliferation and the production of Th1 cytokines independently of the B7-CD28 pathway $(9,10)$. Although LIGHT has three receptors - HVEM, lymphotoxin $\beta$ receptor $(\mathrm{LT} \beta \mathrm{R})$, and DcR3/TR6 $(11,12)-$ HVEM is the primary receptor for $T$ cell costimulation by LIGHT, since LT $\beta R$ is not expressed on T cells (13) and DcR3/TR6 protein is found only in soluble form (14). Blockade of LIGHT-HVEM costimulation by either anti-HVEM mAb, HVEM-Ig, or LT $\beta$ R-Ig fusion protein inhibits allogeneic $\mathrm{T}$ cell responses $(9,10,15)$. Furthermore, in vivo administration of LT $\beta$ R-Ig or anti-LIGHT Ab inhibits anti-host cytotoxic $\mathrm{T}$ lymphocyte (CTL) responses in a murine acute GVHD model, leading to improved survival of recipients (9).

Studies using anti-CD40L mAb and CD40L-deficient mice have demonstrated a critical role of CD40-CD40L interaction in the initiation, expansion, and maintenance of cell-mediated and humoral immune responses $(16,17)$. After stimulation with CD40, antigen-presenting cells, including $B$ cells and dendritic cells, undergo maturation steps accompanied by increased 
expression of MHC class II, B7-1, and B7-2, as well as secretion of IL-12 (18), leading to efficient triggering of $\mathrm{T}$ cell responses (19). Consistent with this notion, blockade of CD40-CD40L interaction has been shown to provide a therapeutic advantage for the prevention of acute and chronic GVHD (6), transplant rejection (20), and autoimmune diseases (21). In mouse models of acute GVHD, a brief treatment course with antiCD40L mAb inhibits proliferation of and Th1 cytokine production by host-reactive $\mathrm{CD} 4^{+} \mathrm{T}$ cells (22), and subsequently interferes with anti-host $\mathrm{CD} 8{ }^{+} \mathrm{CTL}$ generation (23). In addition, GVHD induced by CD28-deficient $\mathrm{T}$ cells has been shown to be inhibited by anti-CD $40 \mathrm{~L} \mathrm{mAb}(24)$, suggesting that blockade of the CD40-CD40L pathway can decrease allogeneic responses independently of B7-CD28 costimulation. Ex vivo manipulation of donor T cells with anti-CD40L $\mathrm{mAb}$ efficiently generates host antigen-specific unresponsiveness and protects recipient mice from GVHD (25), although in vivo administration of anti-CD40L $\mathrm{mAb}$ was only partially effective in preventing GVHD lethality under the same GVHD conditions.

In this report, we describe a powerful method for achieving complete protection of recipient mice from acute GVHD and immunological tolerance using a combined administration of LT $\beta \mathrm{R}-\mathrm{Ig}$ and anti-CD $40 \mathrm{~L}$ $\mathrm{mAb}$. The mechanisms of tolerance induction by costimulatory blockade were explored.

\section{Methods}

Mice. Female C57BL/6J (B6, H-2 $)$, DBA/2J (H-2 $\left.{ }^{\mathrm{d}}\right)$, and F1 $(\mathrm{B} 6 \times \mathrm{DBA} / 2 \mathrm{~J})(\mathrm{BDF} 1)$ mice were purchased from the National Cancer Institute (Frederick, Maryland, USA). Ly5-congenic B6.SJL-Ly5 $5^{a}$ ptprc ${ }^{a}$ pep $3^{b}$ (B6.Ly5.1), C.H-2 ${ }^{\mathrm{bm} 1}(\mathrm{bm} 1)$, and C.H-2 $2^{\mathrm{bm} 12}(\mathrm{bm} 12)$ mice were purchased from The Jackson Laboratory (Bar Harbor, Maine, USA). B6 2C (H-2 $\left.{ }^{\mathrm{b}}\right)$ and B6 OT-I (H-2 $\left.{ }^{\mathrm{b}}\right) \mathrm{T}$ cell receptor (TCR) transgenic mice were developed by $\mathrm{F}$. Carbone (Department of Microbiology and Immunology, Melbourne University, Victoria, Australia) and D.Y. Loh (Washington University, St. Louis, Missouri, USA), respectively. All mice were maintained in the Animal Facility at the Mayo Clinic.

Cell lines, fusion protein, and $A b$ 's. P815 mouse mastocytoma cells (DBA/2, H-2d), EL4 mouse T cell lymphoma cells (B6, H-2 ${ }^{\mathrm{b}}$ ), and E.G7 cells (a chicken ovalbumin-transfected [OVA-transfected] EL4 line) $\left(\mathrm{H}-2^{\mathrm{b}}\right)$ were purchased from the American Type Culture Collection (Rockville, Maryland, USA). AG104A sarcoma cells $\left(\mathrm{H}-2^{\mathrm{k}}\right)$ were a gift from Hans Schreiber (University of Chicago, Chicago, Illinois, USA). All cell lines were maintained in a complete medium (9).

Mouse LT $\beta$ R-Ig fusion protein was prepared as described (9). Anti-CD40L mAb was purified from the supernatants of hybridoma MR1 (26). Purified human IgG1 and hamster IgG were purchased from Sigma Chemical Co. (St. Louis, Missouri, USA) and Rockland Immunochemicals Inc. (Gilbertsville, Pennsylvania, USA), respectively. Anti-2C TCR mAb was purified from the supernatants of hybridoma 1B2 (27) and further conjugated with phycoerythrin in our laboratory.

Mouse GVHD model. The mouse model of acute GVHD was described previously (9). Briefly, splenocytes $\left(7 \times 10^{7}\right)$ from $B 6$ mice were injected intravenously into sublethally irradiated (6 Gy) BDF1 recipients on day 0. The irradiated recipient mice were intravenously administered $100 \mu \mathrm{g}$ of anti-CD $40 \mathrm{~L}$ on day 0 or $100 \mu \mathrm{g}$ of LTRR-Ig on days 0,3 , and 6 , or a combination of both after transplantation. Hamster IgG and human IgG1 were used as controls for anti-CD40L and LT $\beta$ R-Ig, respectively. The recipient mice were monitored for survival daily, and body weight was measured every 5 days. For CTL assay, the recipient spleen cells were harvested on day 7 and assessed by a standard ${ }^{51} \mathrm{Cr}$ release assay (28) without prior in vitro restimulation. Alternatively, B6.Ly5.1 spleen cells $\left(7 \times 10^{7}\right)$ were injected intravenously into irradiated BDF1 recipients, followed by treatment with anti-CD40L and LT $\beta$ R-Ig as described. On day 9, B6 Ly5.1+ donor cells were purified from recipient spleen cells using VarioMACS (Miltenyi Biotec, Auburn, California, USA), in which Ly5.1+ cells were labeled with beads followed by trapping in LS column placed at magnetic fields. Purified Ly5.1 ${ }^{+}$donor cells $\left(2 \times 10^{6} \mathrm{cells} / \mathrm{ml}\right)$ were cultured with irradiated $(30 \mathrm{~Gy})$ DBA $/ 2$ spleen cells at $2 \times 10^{6}$ cells $/ \mathrm{ml}$ for 5 days, and the CTL activity was assessed by a ${ }^{51} \mathrm{Cr}$ release assay.

For examination of $\mathrm{CD}^{+} \mathrm{T}$ cell and $\mathrm{CD}^{+} \mathrm{T}$ cell effects on isolated MHC disparities, bm12 or bm1 recipients were sublethally irradiated (6 Gy) and injected with purified $\mathrm{CD}^{+}\left(1 \times 10^{5}\right.$ cells/recipient) or $\mathrm{CD}^{+}$ $\left(3 \times 10^{5}\right.$ or $1 \times 10^{6}$ cells/recipient) lymph node $(\mathrm{LN}) \mathrm{T}$ cells from B6 mice. Either control Ig or LT $\beta R$-Ig (100 $\mu \mathrm{g})$ was injected intraperitoneally or intravenously beginning on day -1 and continuing either every other day until day 21 or every 3 days until day 14 after transfer. No differences were noted in results from the two schedules of Ig treatment (data not shown), so data were pooled for analysis.

In the $2 \mathrm{C}$ T cell transfer model, $4 \times 10^{7} \mathrm{LN}$ cells from 2C TCR transgenic mice were injected intravenously into sublethally irradiated BDF1 or B6 recipients on day 0 ; mice were subsequently treated with injections of anti-CD40L and LT $\beta$ R-Ig as described above. On day 5 and day 15 , recipient spleen cells were harvested and assessed for CTL activity against P815 cells without in vitro restimulation. The number of $2 \mathrm{C} T$ cells and their expression of CD62L were examined by flow cytometry.

In vivo transfer and in vitro culture of OT-I T cells. OT-I TCR transgenic LN cells, $20-40 \%$ of which are specific for an $\mathrm{H}-2^{\mathrm{b}}$-restricted OVA epitope (SIINFEKL), were combined with either B6.Ly5.1 or BDF1 spleen cells $\left(3 \times 10^{7}\right.$ cells each). These were then infused intravenously into irradiated BDF1 recipients. Mice were subsequently treated with anti-CD40L and LT $\beta$ R-Ig as described above. Eight days after cell transfer, OT-I T cells in recipient spleens were enriched by depletion of Ly5.1 $1^{+}$and $\mathrm{H}-2 \mathrm{~K}^{\mathrm{d}+}$ cells by VarioMACS. The enriched 
cells were plated at $1.5 \times 10^{6}$ cells $/ \mathrm{ml}$ and stimulated with $10 \mathrm{ng} / \mathrm{ml}$ OVA peptide in the presence of irradiated B 6 spleen cells at $1.5 \times 10^{6}$ cells $/ \mathrm{ml}$ for 4 days. The CTL activity against non-pulsed EL4 cells, OVA peptide-pulsed $(10 \mu \mathrm{g} / \mathrm{ml})$ EL4 cells, and EG7 cells was assessed by a standard ${ }^{51} \mathrm{Cr}$ release assay.

Allogeneic BM reconstitution. To generate allogeneic BM-reconstituted mice, B6 BM cells were first depleted of $T$ cells using the VarioMACS system with antiThy1.2 mAb-conjugated microbeads. Then lethally irradiated (11 Gy) BDF1 mice were injected intravenously with $5 \times 10^{6} \mathrm{~T}$ cell-depleted $\mathrm{BM}$ cells. Six weeks later, reconstitution of host lymphoid tissues by donor cells was confirmed by flow cytometry by double staining with $\mathrm{H}-2 \mathrm{~K}^{\mathrm{d}}$ and $\mathrm{H}-2 \mathrm{~K}^{\mathrm{b}}$ (data not shown). Anti-host CTL induction in vitro and in vivo. Spleen cells from either naive $\mathrm{B} 6$ mice, long-term GVHD survivors, or B6 BM-reconstituted BDF1 mice were stimulated with irradiated (30 Gy) DBA/2 spleen cells $\left(2 \times 10^{6}\right.$ cells $/ \mathrm{ml}$ each) in the presence or absence of $10 \mathrm{IU} / \mathrm{ml}$ of human IL-2 (Cetus Corp., Emeryville, California, USA). After 5 days, CTL activity against P815 cells was measured by a ${ }^{51} \mathrm{Cr}$ release assay. In addition, spleen cells $\left(5 \times 10^{7}\right.$ cells) from either naive B6 mice, long-term GVHD survivors, or B6 BM-reconstituted BDF1 mice were transferred intravenously on day 0 into secondary BDF1 recipient mice. In some groups, recombinant human IL-2 at a dose of 50,000 IU/day was injected intraperitoneally after spleen cell transfer. After 10 days, CTL activity of recipient spleen cells against P815 cells was assessed. Expansion of donor T cells and elimination of host $\mathrm{B}$ cells was quantified by flow cytometry by double staining with $\mathrm{H}-2 \mathrm{~K}^{\mathrm{d}}$ and $\mathrm{CD} 3$.

Statistical analysis. Group comparisons of continuous data were analyzed by Student $t$ test. For survival data, Kaplan-Meier survival curves were prepared using StatView 5.0 software (SAS Institute Inc., Cary, North Carolina, USA), and statistical differences were analyzed using the log-rank (Mantel-Cox) test. $P$ values lower than 0.05 were considered significant.

\section{Results}

Synergistic effects of LT $\beta R$-Ig and anti-CD $40 \mathrm{~L} m A b$ in the prevention of GVHD are accompanied by profound inbibition of anti-host CTLs. Upon transfer of B6 T cells, recipient BDF1 mice generate acute GVHD characterized by rapid weight loss, expansion of host-reactive donor $\mathrm{T}$ cells, shrinkage of the thymus, and eventual death (Figure 1, a and $b$, and data not shown). Infusion of LT $\beta R$-Ig, which blocks the LIGHT costimulatory pathway $(9,10)$, significantly reduced GVHD mortality as well as anti-host CTL activity. The treatment is not optimal because approximately $20 \%$ of mice still die of GVHD. However, combined treatment with anti-CD40L and LT $\beta$ R-Ig in our study prevented death in $100 \%$ of recipient mice, whereas anti-CD40L treatment alone protected only about $50 \%$ of mice (Figure 1a). Combined therapy protected all recipient mice from death for more than 90 days (Figure 1a), and efficiently prevented weight loss in recipient mice (Figure 1b). This combined therapy also profoundly inhibited the generation of anti-host $\left(\mathrm{H}-2^{\mathrm{d}}\right)$ CTL activity, whereas treatment by anti-CD40L alone did not affect CTL activity, and LT $\beta$ R-Ig alone resulted in a partial inhibition (Figure 1c).

It has been suggested that the blockade of CD40CD40L interaction prevents GVHD through a $\mathrm{CD} 4^{+}$ but not $\mathrm{CD}^{+} \mathrm{T}$ cell-mediated mechanism (22). To investigate the differential effects of LT $\beta \mathrm{R}-\mathrm{Ig}$ on $\mathrm{CD} 4^{+}$ and $\mathrm{CD}^{+} \mathrm{T}$ cell-mediated GVHD, sublethally irradiated bm12 and bm 1 recipients were injected intravenously with purified $\mathrm{B} 6 \mathrm{CD}^{+}$and $\mathrm{CD}^{+} \mathrm{T}$ cells, respectively. Infusion of LT $\beta R$-Ig significantly prolonged the survival of $b m 1$ recipients of a minimum uniformly lethal dose of $\mathrm{CD}^{+} \mathrm{T}$ cells (Figure 1d). In contrast, survival was not significantly prolonged in bm 12 recipients given a minimum uniformly lethal dose of $\mathrm{CD}^{+} \mathrm{T}$ cells (Figure 1e). Thus, LT $\beta$ R-Ig treatment is more effective in inhibiting $\mathrm{CD}^{+} \mathrm{T}$ cell-mediated GVHD than $\mathrm{CD}^{+} \mathrm{T}$ cell-mediated GVHD under these conditions. Our results suggest that the synergistic effect of anti-CD $40 \mathrm{~L} \mathrm{mAb}$ and LT $\beta \mathrm{R}-\mathrm{Ig}$ in our model is mediated by inhibition of both $\mathrm{CD}^{+}$and $\mathrm{CD}^{+}$host-reactive $\mathrm{T}$ cells.

Combined therapy inbibits the generation of anti-host CTL activity without peripheral deletion of $T$ cells. To trace $T$ cells in the recipients after treatment with costimulatory blockade, we used 2C TCR transgenic T cells as donor cells. $2 \mathrm{C} \mathrm{T}$ cells react specifically against $\mathrm{H}-2 \mathrm{~L}^{\mathrm{d}}$ antigen and express a defined $\mathrm{T}$ cell receptor that can be specifically identified (27). 2C T cells that were transferred into BDF1 mice expanded vigorously and generated a high level of anti-host CTL activity, as early as 5 days after cell transfer (Table 1). Similar to the results obtained from polyclonal $\mathrm{T}$ cell transfer shown in Figure $1 c$, injections of LT $\beta R$-Ig, but not anti-CD $40 \mathrm{~L} \mathrm{mAb}$, significantly inhibited CTL activity. Nearly complete inhibition of 2C CTL activity was observed in recipients treated with a combination of LT $\beta$ R-Ig and anti-CD40L $\mathrm{mAb}$. Inhibition of antigen-specific CTL generation was noted through day 15 after transfer, although cell counting taken on both day 5 and day 15 showed that 2C T cells in treated recipients had expanded as vigorously as those in control recipients (Table 1). Our data thus suggest that combined treatment with LT $\beta$ R-Ig and anti-CD40L mAb inhibits anti-host CTL generation without deletion of host-reactive $T$ cells.

After transfer into syngeneic $\mathrm{B} 6$ recipients, the percentage of 2C T cells expressing a low level of CD62L $\left(\mathrm{CD} 62 \mathrm{~L}^{\text {low }}\right)$, which indicates an antigen-experienced phenotype (29), remained constant in the range of $10-20 \%$ (Table 1 ). In contrast, the majority of $2 \mathrm{C} \mathrm{T}$ cells transferred into BDF1 recipients converted to $\mathrm{CD} 62 \mathrm{~L}^{\text {low }}$ cells as early as 5 days after transfer. The combined therapy delayed downregulation of CD62L expression on 2C T cells, an effect that was accompanied by suppressed CTL activity. However, a significant number of $2 \mathrm{C} T$ cells had converted to CD62 L $\mathrm{L}^{\text {low }}$ cells by day 15 , even though CTL activity remained low. A similar pattern was observed 
a

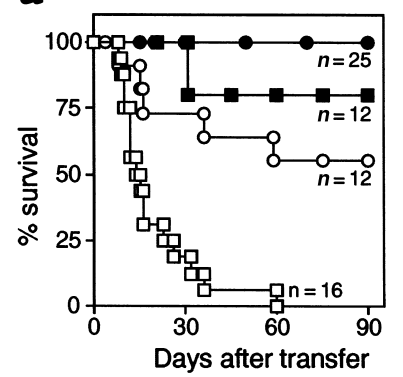

b

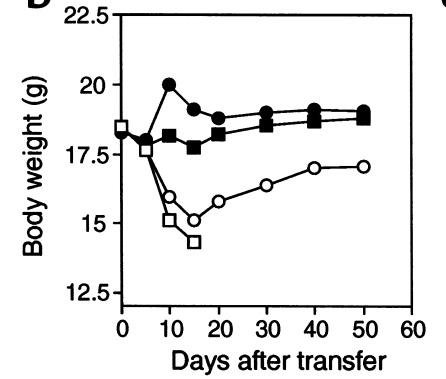

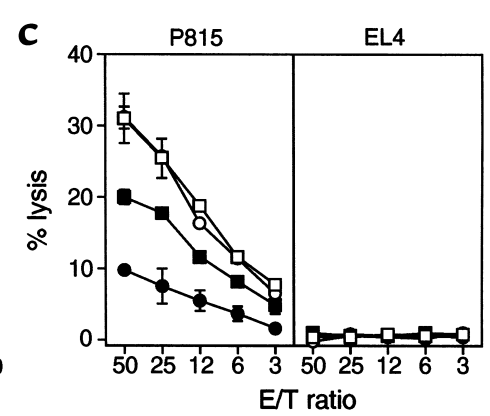

d

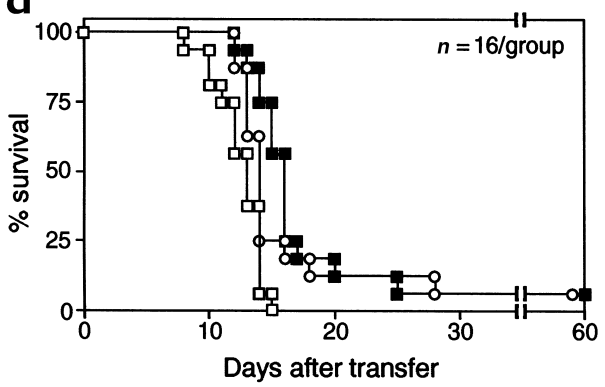

e

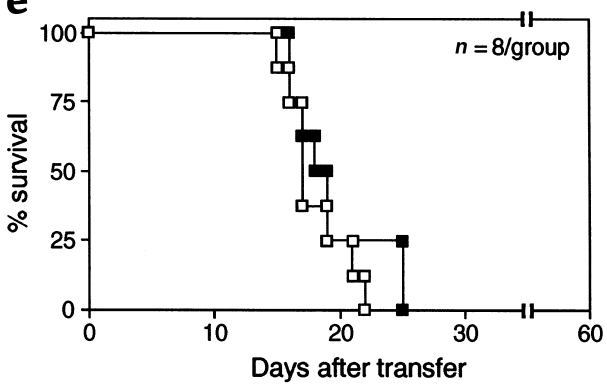

Figure 1

Synergistic effect of LT $\beta R$-Ig and anti-CD40L mAb in amelioration of GVHD and inhibition of anti-host CTL activity. (a-c) B6 splenocytes $\left(7 \times 10^{7}\right.$ cells) were injected into sublethally irradiated BDF1 mice and treated with either anti-CD40L (open circles), LT $\beta R$-Ig (filled squares), or both (filled circles). Hamster IgG and human IgG1 were injected as control (open squares). (a) Survival of recipients was examined daily, and pooled data from four independent experiments are presented. Treatment with both anti-CD40L and LT $\beta R$-Ig significantly prolonged survival compared to other treatments $(P<0.05)$. (b) Average body weight. Symbols same as for a. (c) The CTL activity of recipient spleen cells against $\mathrm{P} 815\left(\mathrm{H}-2^{\mathrm{d}}\right)$ and EL4 $\left(\mathrm{H}-2^{\mathrm{b}}\right)$ was examined on day 7 without in vitro restimulation. Results are expressed as the mean $\pm \mathrm{SD}$ of triplicate wells. (d) Purified B6 CD8 $8^{+}$cells $\left(1 \times 10^{6}\right.$ cells) were injected into sublethally irradiated bm 1 mice followed by treatment with LT $\beta$ R-Ig (filled squares) or control Ig (open squares) as described in Methods. Recipients of LT $\beta$ R-Ig had a significantly $(P=0.0002)$ higher survival rate than did control-treated recipients. The reduction in GVHD lethality by LT $\beta R$-Ig treatment was estimated to be approximately equivalent to that resulting in control-treated mice from a threefold lower number $\left(3 \times 10^{5}\right)$ of $\mathrm{CD} 8^{+}$cell transfer (open circles, $\left.P>0.1\right)$. $(\mathbf{e})$ Purified B6 CD4+ $T$ cells $\left(1 \times 10^{5}\right.$ cells) were injected into sublethally-irradiated bm 12 mice followed by treatment with LT $\beta R$-lg (filled squares) or control Ig (open squares) as described in Methods. No significant difference $(P>0.1)$ was noted between these two groups.

using CD44 marker (data not shown). Taken together, our results suggest that combined treatment with $\mathrm{LT} \beta \mathrm{R}-\mathrm{Ig}$ and anti-CD40L mAb inhibits the effector function, but is less effective at inhibiting the priming and expansion of host-reactive CTLs.

Combined therapy leads to repopulation of donor-derived lymphocytes in long-term GVHD-surviving mice. In the recipients that received the combined treatment and survived GVHD more than 60 days after transfer of B6 splenocytes, all lymphohematopoietic cells were $\mathrm{H}-2 \mathrm{~K}^{\mathrm{b}+}$ and $\mathrm{H}-2 \mathrm{~K}^{\mathrm{d}-}$, indicating complete replacement of the recipient lymphoid system by donor cells. Repopulation of donor lymphocytes was observed in spleen, LNs (Figure 2a), thymus (Figure 2b), and BM (data not shown). In addition, proportions of $\mathrm{T}$ cells, $\mathrm{B}$ cells, and $\mathrm{CD} 4^{+}$ and $\mathrm{CD}^{+} \mathrm{T}$ cell subsets in spleen, $\mathrm{LN}$, and thymocyte subsets were similar to those in naive B6 mice. Myeloid cells expressing Mac-1 also converted to donor-derived cells (data not shown). The proportion of CD62 $\mathrm{L}^{\text {low }}$ cells in recipient splenic and LN T cells, however, increased significantly compared with that in naive B6 mice (Figure $3 \mathrm{a}$ ), suggesting constant exposure of $\mathrm{T}$ cells to host antigens. Similar results were also observed using $2 \mathrm{C} \mathrm{T}$ cells as a donor source (Figure $3 b$ ). In this system, trans- ferred 2C T cells were present more than 60 days in BDF1 recipients treated with the combined therapy and were comparable in number to those transferred into control B6 recipients. Importantly, a significant increase of CD62 $\mathrm{L}^{\text {low }}$ cells was detected in 2C T cells in BDF1 recipients compared with those in $\mathrm{B} 6$ recipients (Figure $3 b)$. Our results thus demonstrate that donor-derived hematopoietic cells can repopulate in treated recipient mice in which antigen-experienced, host-reactive $T$ cells persist long-term, without inducing GVHD.

Tolerance induced by combined therapy did not affect $T$ cell responses to nominal antigens. To examine whether the tolerance is "infectious," we used OT-I T cells, which express a transgenic TCR that uniformly reacts with OVA antigen in the context of $\mathrm{H}-2 \mathrm{~K}^{\mathrm{b}}(30)$, to facilitate isolation of antigen-reactive T cells. A mixture of OT-I $\mathrm{T}$ cells and B6.Ly5.1 splenocytes was transferred into BDF1 recipient mice, followed by combined treatment with LT $\beta$ R-Ig and anti-CD40L mAb to induce tolerance. As a control, OT-I T cells mixed with BDF1 splenocytes were transferred into BDF1 recipients in which GVHD was not induced. Transferred OT-I T cells were recovered from recipient spleen by enrichment of a subpopulation that was negative for both $\mathrm{H}-2 \mathrm{~K}^{\mathrm{d}}$ and 
Table 1

Modification of 2CT cell functions by blockade of LIGHT and CD40L costimulators

\begin{tabular}{|c|c|c|c|c|c|c|c|}
\hline $\begin{array}{l}\text { Day after } \\
\text { transfer }\end{array}$ & Recipient & Treatment & $50: 1$ & $\begin{array}{c}\text { Percent lysis }{ }^{A} \\
25: 1\end{array}$ & $12.5: 1$ & $\begin{array}{l}\text { 2C T cells } \\
\left(\times 10^{5}\right)\end{array}$ & $\begin{array}{l}\text { Percent CD62Llon } \\
\text { in } 2 C T \text { cells }\end{array}$ \\
\hline Day 5 & $\begin{array}{l}\text { B6 } \\
\text { BDF1 } \\
\text { BDF1 } \\
\text { BDF1 } \\
\text { BDF1 }\end{array}$ & $\begin{array}{c}\text { Control Ig } \\
\text { Control Ig } \\
\text { Anti-CD40L } \\
\text { LT } \beta R-\text { Ig } \\
\text { Anti-CD40L/LT } \beta R \text {-Ig }\end{array}$ & $\begin{aligned} 3.2 & \pm 0.6 \\
25.2 & \pm 2.9 \\
30.9 & \pm 1.2 \\
15.4 & \pm 4.4 \\
4.3 & \pm 2.1^{\mathrm{D}}\end{aligned}$ & $\begin{array}{r}1.2 \pm 0.3 \\
23.7 \pm 0.5 \\
29.1 \pm 1.2 \\
14.4 \pm 4.1^{\mathrm{C}} \\
4.4 \pm 1.3^{\mathrm{D}}\end{array}$ & $\begin{aligned} 1.0 & \pm 1.1 \\
20.0 & \pm 2.5 \\
22.7 & \pm 0.7 \\
11.1 & \pm 3.0^{\mathrm{C}} \\
2.0 & \pm 1.1^{\mathrm{D}}\end{aligned}$ & $\begin{array}{l}8.6 \\
56.2 \\
68.6 \\
50.9 \\
60.7\end{array}$ & $\begin{array}{l}18.6 \\
72.6 \\
72.3 \\
45.9 \\
35.3\end{array}$ \\
\hline Day 15 & $\begin{array}{l}\text { B6 } \\
\text { BDF1 } \\
\text { BDF1 }\end{array}$ & $\begin{array}{c}\text { Control Ig } \\
\text { Control Ig } \\
\text { Anti-CD40L/LT } \beta R \text {-Ig }\end{array}$ & $\begin{aligned} 0.2 & \pm 0.5 \\
12.6 & \pm 0.7 \\
6.8 & \pm 0.8^{\mathrm{D}}\end{aligned}$ & $\begin{array}{r}0.4 \pm 0.6 \\
11.2 \pm 1.8 \\
4.6 \pm 0.5^{\mathrm{D}}\end{array}$ & $\begin{array}{l}0.0 \pm 1.3 \\
8.6 \pm 0.9 \\
2.9 \pm 1.3^{D}\end{array}$ & $\begin{array}{l}18.8 \\
68.0 \\
70.1\end{array}$ & $\begin{array}{l}15.1 \\
70.5 \\
56.2\end{array}$ \\
\hline
\end{tabular}

Sublethally irradiated B6 or BDF1 recipient mice were injected intravenously with $2 \mathrm{C}$ T cells and then treated with either anti-CD40L (100 $\mu \mathrm{g}$ ) on day 0 , LT $\beta \mathrm{R}-\mathrm{Ig}$ $(100 \mu \mathrm{g})$ on days 0,3 , and 6 , or both treatments together. As a control, the same amount of hamster IgG and human IgG1 were injected into sublethally irradiated B6 or BDF1 mice on the same schedule. ${ }^{\mathrm{A} C T L}$ activity of recipient spleen cells against $\mathrm{H}-2^{\mathrm{d}}$ target (P815) cells at the indicated effector:target ratio, measured without in vitro manipulation. ${ }^{B}$ Number of $2 \mathrm{CT}$ cells was calculated by multiplication of spleen cell number by a percentage of $1 \mathrm{~B} 2{ }^{+} \mathrm{CD} 8^{+} \mathrm{T}$ cells $(\mathrm{average}$ of $2-3$ recipients in each group). ${ }^{C} P<0.05,{ }^{D} P<0.01$ compared with BDF1 recipients treated with control Ig. Similar results were obtained in three repeated experiments

Ly5.1. After in vitro restimulation with antigenic OVA peptide, OT-I T cells recovered from the tolerant recipients generated significant CTL activity against OVA peptide-pulsed EL4 cells and E.G7 cells, but not nonpulsed EL4 cells. CTL activity of these OT-I T cells was identical to that of OT-I T cells purified from control recipients (Figure 4). CTL activity of OT-I T cells can be inhibited when antigenic OVA peptide is administered to mice receiving transferred OT-I T cells (data not shown). These data demonstrate that $\mathrm{T}$ cell tolerance to allogeneic antigens induced by combined therapy does not inhibit the responsiveness of nonalloreactive $\mathrm{T}$ cells to other antigens.

Combined therapy induces an early and persistent anergy of host-reactive CTLs. The hallmark of T cell tolerance is its unresponsiveness to antigen in the presence of appropriate antigen-presenting cells (31). We first examined whether $\mathrm{T}$ cells isolated from tolerant mice can be induced to resume their CTL activity. As shown in Figure 5a, B6.Ly5.1 T cells, which were isolated from BDF1 mice 9 days after combined therapy and restimulated in vitro by allogeneic DBA/2 spleen cells as a source of $\mathrm{H}-2^{\mathrm{d}}$ antigens, failed to lyse $\mathrm{H}-2^{\mathrm{d}+}$ target cells. In contrast,
B6.Ly5.1 donor cells transferred into syngeneic $\mathrm{B} 6$ recipients mounted considerable CTL activity in an $\mathrm{H}-2^{\mathrm{d}}$-specific manner after in vitro restimulation. Our results indicate that combined treatment with LT $\beta$ R-Ig and anti-CD40L $\mathrm{mAb}$ can induce donor $\mathrm{T}$ cell anergy to allogeneic antigens in an early phase of $\mathrm{T}$ cell activation.

Host-reactive CTL activity was also assessed in tolerant mice more than 60 days after combined treatment was completed. No CTL activity against P815 target cells ( $\mathrm{H}-2^{\mathrm{d}}$ cells) was detected, using spleen cells from tolerant mice, when the cells were directly used as effectors without further restimulation (Figure 5b). Upon restimulation with irradiated splenocytes from DBA/2 mice as a source of antigen-presenting cells expressing $\mathrm{H}-2^{\mathrm{d}}$ antigens, CTL activity specific to P815 target cells could be detected in spleen cells from tolerant mice. The level of CTL activity, however, was significantly lower than that in cells from the positive control, in which CTLs were generated from splenocytes of naive B6 mice 5 days after coculture with allogeneic DBA/2 spleen cells (Figure 5c). In addition, the decreased CTL activity in tolerant mice could be restored in vitro to a level comparable to that induced in naive $\mathrm{B} 6$ mice by

\section{Figure 2}

Repopulation of donor-derived lymphocytes in GVHD-surviving recipients. Sublethally irradiated BDF1 recipients were given $\mathrm{B} 6$ spleen cells $\left(7 \times 10^{7}\right.$ cells) and subsequently treated with a combination of anti-CD40L and LT $\beta$ R-Ig. More than 60 days later, the recipient spleen cells, LN cells (a), and thymocytes (b) were stained with mAb's against indicated antigens conjugated with FITC or phycoerythrin and subsequently analyzed by flow cytometry. Similar data was obtained from eight independent mice surviving GVHD. Numbers in the figure represent the percentage of lymphocytes located in the same quadrants.
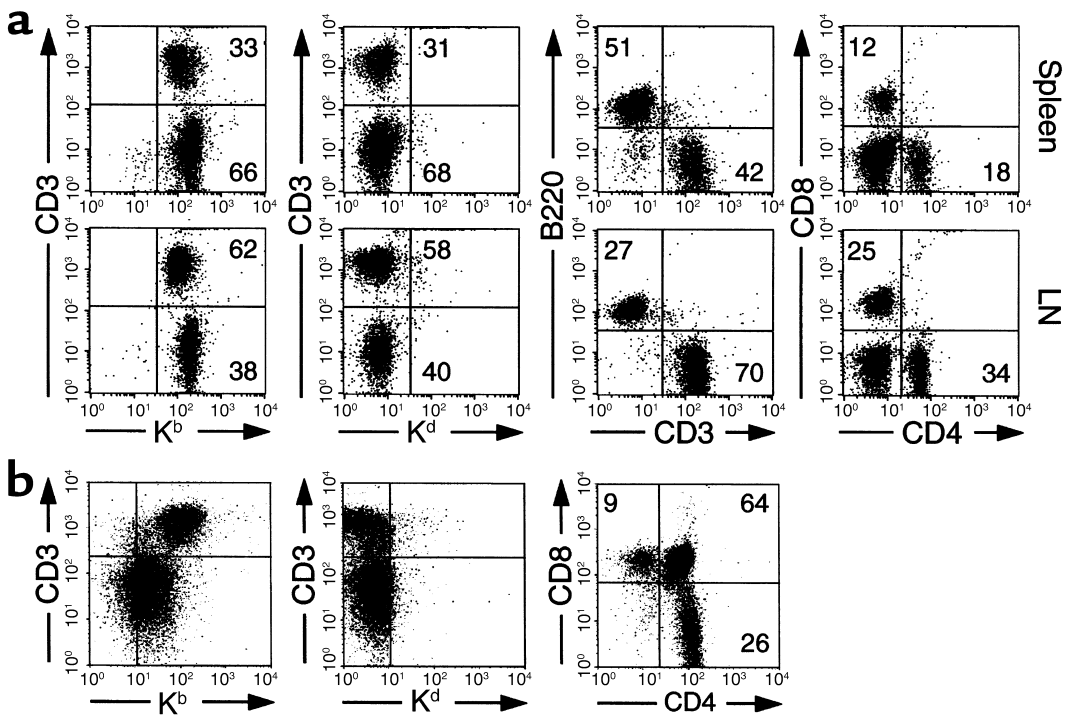
a

Naive B6

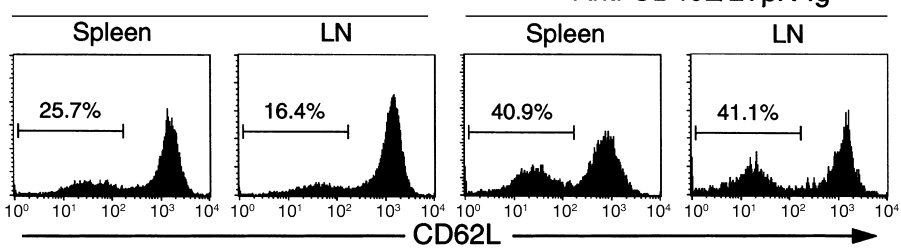

$2 \mathrm{C}$ into $\mathrm{B} 6$
$\mathrm{Control}$ lg

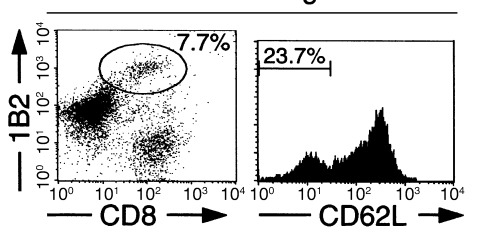

B6 into BDF1

Anti-CD40L/LT $\beta R$-Ig

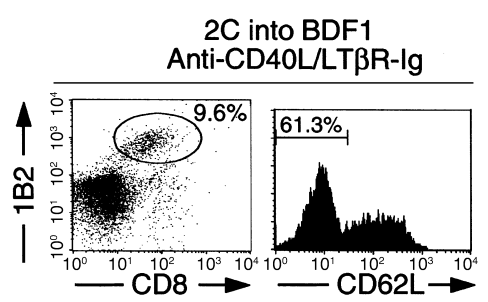

\section{Figure 3}

Persistence of host-reactive T cells in long-term GVHD survivors. (a) In naive B6 and GVHD-surviving mice (more than 60 days), spleen and LNs were stained with anti-CD3 and anti-CD62L mAb's and examined for CD62L expression of CD3-positive cells. (b) Sublethally irradiated $\mathrm{B} 6$ or $\mathrm{BDF} 1$ recipient mice received $4 \times 10^{7}$ LN cells from 2C TCR transgenic mice on day 0 . BDF1 recipients were treated with anti-CD40L $(100 \mu \mathrm{g}$, on day 0$)$ and LT $\beta R$-Ig (100 $\mu$ g on days 0,3 , and 6$)$, whereas control Ig was injected into B6 recipients. More than 60 days later, recipient spleen cells were stained with anti-CD8, 1B2, and anti-CD62L mAb's. $\mathrm{CD} 62 \mathrm{~L}$ expression of $\mathrm{CD} 8^{+} 1 \mathrm{~B} 2^{+}$double-positive cells was examined. Numbers in the figure represent the percentage of $2 \mathrm{C} \mathrm{T}$ cells $(\mathbf{b})$ and the percentage of CD62 Llow cells ( $\mathbf{a}$ and $\mathbf{b})$. addition of IL-2 (Figure 5d). As a negative control, spleen cells from BDF1 mice that had been reconstituted with $\mathrm{T}$ cell-depleted B6 BM cells did not induce any CTL activity (Figure 5c), probably because of negative selection of host-reactive $\mathrm{T}$ cells in the thymus.

Although cytolytic activity of host-reactive $\mathrm{T}$ cells in tolerant mice can be recovered in vitro by exposure to appropriate antigens, antigen-presenting cells, and cytokines, it is not known whether the same environment exists in vivo. To address this point, spleen cells from recipients tolerized by combined therapy were transferred into naive BDF1 recipient mice. Transfer of naive $\mathrm{B} 6$ splenocytes mediated profound $\mathrm{H}-2^{\mathrm{d}}$-specific CTL activity in the recipients. In contrast, BDF1 mice receiving splenocytes transferred from the tolerized mice or from B6 BM-reconstituted BDF1 mice did not generate CTLs (Figure 6a), in spite of a comparable number of $\mathrm{T}$ cells in transferred cells (Figure 2a). Administration of 50,000 IU/day IL-2 (Figure 6a) or 50 $\mu \mathrm{g}$ of LPS (data not shown) did not reverse the tolerant state of allogeneic $\mathrm{T}$ cells. Furthermore, vigorous expansion of donor T cells $\left(\mathrm{CD}^{+} \mathrm{H}-2 \mathrm{~K}^{\mathrm{d}-}\right)$, along with the elimination of host $\mathrm{B}$ cells $\left(\mathrm{CD} 3-\mathrm{H}-2 \mathrm{~K}^{\mathrm{d}+}\right)$ - typical consequences of acute GVHD - were observed after transfer of naive B6 spleen cells but not after transfer of B6derived cells present in BDF1 hosts tolerized by combined therapy or by $\mathrm{B} 6 \mathrm{BM}$ reconstitution (Figure 6b). Therefore, despite recovery of CTL activity by in vitro manipulation, anergic $\mathrm{T}$ cells in the mice given combined therapy remained tolerant in vivo even in the presence of corresponding antigens and exogenous IL-2.

\section{Discussion}

In this study, we have developed a new method to completely prevent acute GVHD in a B6 to BDF1 T cell transfer model. Combined administration of LT $\beta$ R-Ig and anti-CD40L mAb induces complete, long-term (more than 90 days) survival of mice receiving immunocompetent allogeneic donor cells that without the combined treatment would induce acute lethal GVHD. In addition, we have demonstrated that the mechanism of this protection is the induction of persistent anergy rather than deletion of CTLs responding to alloantigens. Furthermore, donor-derived cells completely replace the recipient's hematopoietic system; this total replacement is associated with long-lasting unresponsiveness to host antigens. Anergy is specific for host-reactive CTLs but not for $\mathrm{T}$ cells reacting to other antigens. Our findings thus suggest a new approach to induce $\mathrm{T}$ cell anergy and to ameliorate GVHD in humans.

It is well-established in murine models that both $\mathrm{CD}^{+}$and $\mathrm{CD}^{+} \mathrm{T}$ cells are capable of mediating GVHD caused by disparities of MHC or minor antigens (32, 33). Taking into account the roles of $\mathrm{CD} 4^{+} \mathrm{T}$ cells in the generation of alloreactive $\mathrm{CD} 8^{+} \mathrm{T}$ cells (34), inhibition of the CD4 arm of the immune response may be neces-

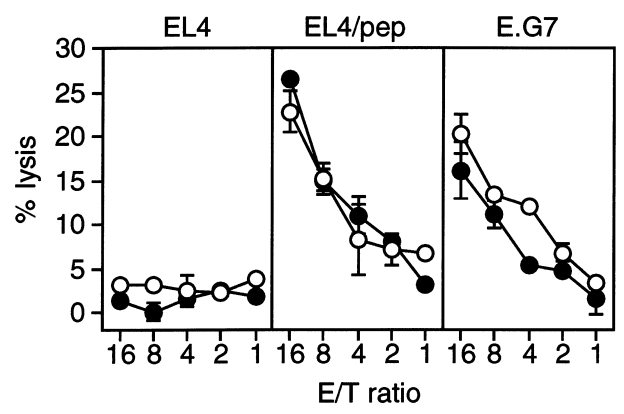

\section{Figure 4}

Intact $\mathrm{T}$ cell responses to nominal antigen in the combined therapy. Sublethally irradiated BDF1 mice received a mixture of OT-I LN cells $\left(3 \times 10^{7}\right.$ cells) and either $3 \times 10^{7}$ BDF1 spleen cells (open circles) or B6.Ly5.1 spleen cells (filled circles) on day 0. Recipients of transferred OT-I LN cells and B6.Ly5.1 cells received anti-CD40L $(100 \mu \mathrm{g}$, on day 0 ) and $L T \beta R-\lg (100 \mu \mathrm{g}$ on days 0,3 , and 6$)$. On day 8 , cell populations negative for both $\mathrm{Ly} 5.1$ and $\mathrm{H}-2 \mathrm{~K}^{\mathrm{d}}$ were enriched from recipient spleen cells by magnetic cell sorting. The purified cells $\left(1.5 \times 10^{6}\right.$ cells $/ \mathrm{ml}$ ) were stimulated with $10 \mathrm{ng} / \mathrm{ml}$ OVA peptide in the presence of irradiated B6 spleen cells $\left(1.5 \times 10^{6}\right.$ cells $\left./ \mathrm{ml}\right)$ for 4 days. The CTL activity against nonpulsed EL4 cells, EL4 cells pulsed with $10 \mu \mathrm{g} / \mathrm{ml}$ of antigenic OVA peptide (EL4/pep), and E.G7 cells was assessed by ${ }^{51} \mathrm{Cr}$ release assay. Results are expressed as mean $\pm \mathrm{SD}$. 

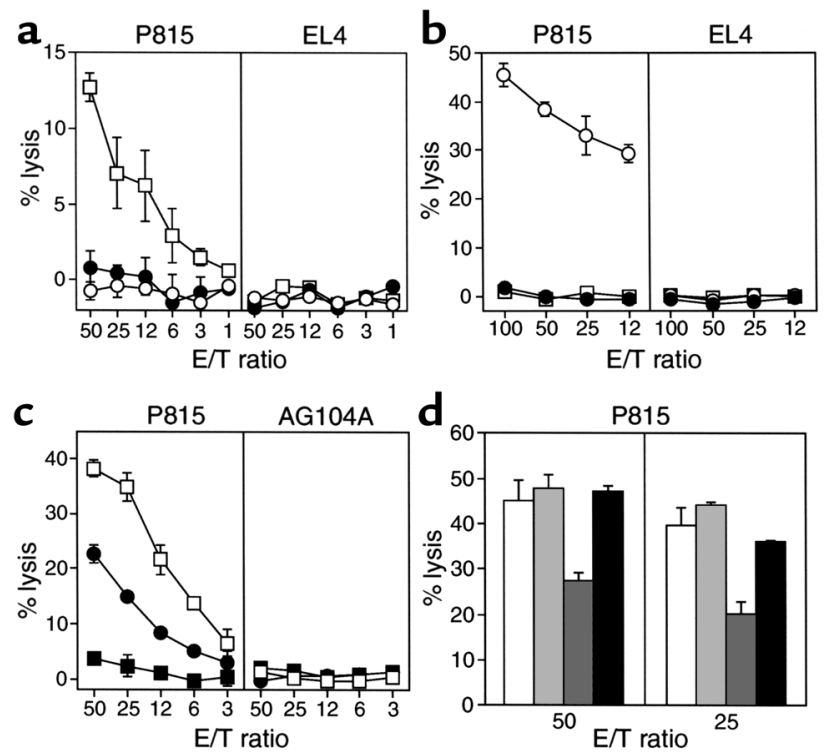

Figure 5

Induction of T cell anergy by combined treatment with LT $\beta$ R-Ig and anti-CD40L mAb. (a) Sublethally irradiated BDF1 (filled circles) or B6 (open squares) mice were infused with B6.Ly5.1 splenocytes together with anti-CD40L and LT $\beta$ R-Ig on day 0. On day 9, B6.Ly5.1+ cells were purified and stimulated with irradiated DBA/2 splenocytes for 5 days. CTL activity against P815 and EL4 was assessed. The same recipient mice were injected with splenocytes from BDF1 mice as the controls (open circles). (b) CTL activity of splenocytes from recipients that survived GVHD more than 60 days was assessed against indicated targets without in vitro culture (filled circles). Splenocytes from BDF1 recipients that had received B6 (open circles) or BDF1 splenocytes (open squares) for 10 days were used as controls. (c) Splenocytes from recipients survived more than 60 days (filled circles) were stimulated for 5 days as described above, and subsequently examined for CTL activity against indicated targets. As controls, splenocytes from naive B6 mice (open squares) or B6 BM-reconstituted BDF1 mice (filled squares) were used as responder cells. (d) Splenocytes from recipients that survived (more than 60 days) were stimulated as described above in the absence (dark gray bars) or presence (black bars) of IL-2. Naive B6 splenocytes were similarly stimulated in the absence (white bars) or presence (light gray bars) of IL-2. After 5 days, CTL activity against P815 cells was examined. Results are expressed as the mean \pm SD of triplicate wells. E/T ratio: ratio of effector cells to target cells in CTL assay.

sary to achieve the maximal effect. Several studies indicate that the primary role of anti-CD40L mAb in the reduction of GVHD lethality is to inhibit the functions of alloreactive $\mathrm{CD} 4^{+} \mathrm{T}$ cells, such as expansion and Th1-type cytokine production (22), which could subsequently limit functional maturation of alloreactive $\mathrm{CD}^{+} \mathrm{T}$ cells (23). In our study, a single dose of antiCD40L mAb did not lead to inhibition of CTL activity in recipients receiving either transferred $\mathrm{B} 6$ spleen cells or $2 \mathrm{C} \mathrm{T}$ cells (Figure $1 \mathrm{c}$ and Table 1), in spite of prolonged survival of approximately $50 \%$ of the recipient mice (Figure 1a). On the other hand, administration of LT $\beta$ R-Ig significantly inhibited anti-host CTL activity, indicating a direct impairment of anti-host $\mathrm{CD}^{+} \mathrm{T}$ cell function. Furthermore, administration of LT $\beta$ R-Ig inhibited GVHD induced by $\mathrm{CD} 8^{+} \mathrm{T}$ cells injected into bm1 mice, but not GVHD induced by $\mathrm{CD}^{+} \mathrm{T}$ cells injected into bm 12 mice. The synergistic effect, however, decreased to minimal in the GVHD model in which recipients received lethal radiation and subsequent transfer of T cell-depleted BM plus allogeneic spleen cells (data not shown). This may reflect decreased dependency on costimulation and $\mathrm{CD}^{+} \mathrm{T}$ cells in lethal radiation-associated GVHD (35). Nevertheless, our results suggest a potential mechanism for the synergistic effects of LT $\beta$ R-Ig and anti-CD $40 \mathrm{~L} \mathrm{mAb}$ in the inhibition of GVHD.

Soluble receptor of LT $\beta$ is reported to bind at least two ligands belonging to the TNF superfamily, LIGHT and LT $\beta$ (11). Recent studies have demonstrated that signaling via LT $\beta$ R by membrane LT $\beta$ is critical for the development and maintenance of secondary lymphoid structures (36) and for maintaining dendritic cells in secondary lymphoid tissues (37). Furthermore, crosslinking of LT $\beta R$ induces the production of IL-8 and RANTES chemokine (38). Therefore, in addition to blockade of the LIGHT-HVEM costimulatory pathway, LT $\beta$ R-Ig could have profound effects on both priming
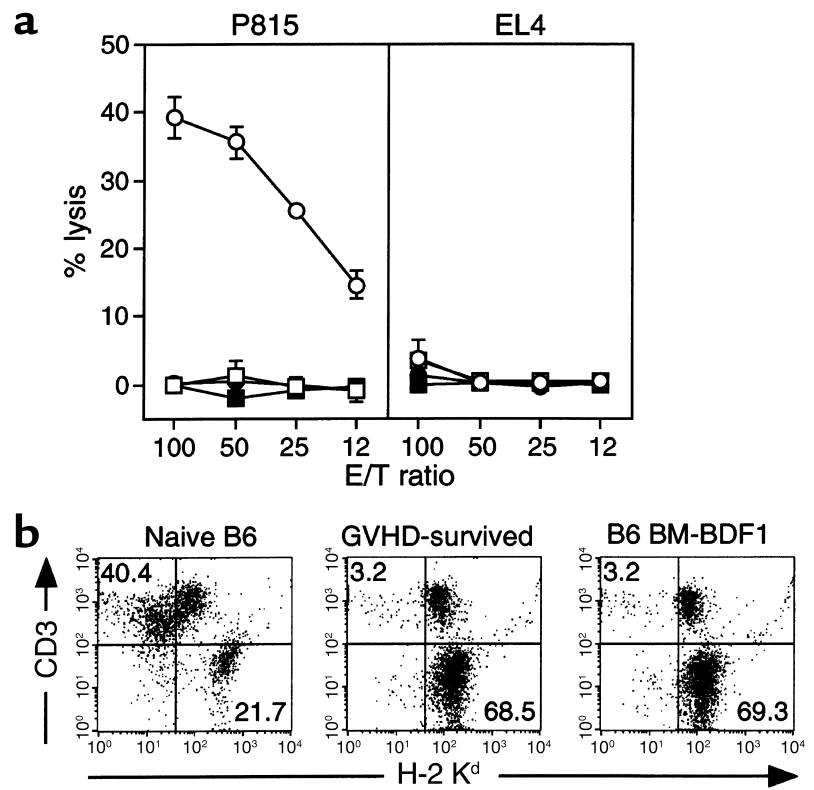

\section{Figure 6}

In vivo tolerance of host-reactive T cells in GVHD-surviving recipients. Spleen cells $\left(5 \times 10^{7}\right.$ cells $)$ from recipient mice that survived GVHD for more than 60 days due to the combined treatment were injected intravenously into secondary BDF1 recipient mice on day 0 (open squares). In some mice, 50,000 IU of IL-2 was injected daily intraperitoneally from day 0 to day 10 (filled squares). As control, either naive B6 spleen cells (open circles) or spleen cells from B6 BM-reconstituted BDF1 mice (filled circles) were injected into BDF1 recipients. (a) After 10 days of cell transfer, recipient spleen cells were examined for CTL activity against P815 and EL4 cells without in vitro culture. Results are expressed as the mean \pm SD of triplicate wells. (b) After 10 days of transfer of spleen cells from either naive B6 mice (left panel), GVHD-surviving mice (center panel), or B6 BM-reconstituted BDF1 mice (right panel), spleen cells of recipient mice were stained with $m A b$ 's against indicated antigens. Numbers in figure represent the percentage of lymphocytes located in that quadrant. 
and migration of $\mathrm{T}$ cells. Our results indicating that administration of LT $\beta$ R-Ig contributes to the induction of $\mathrm{T}$ cell tolerance suggests a new function of LT $\beta R$ and HVEM receptor signaling in the regulation of peripheral $\mathrm{T}$ cell responses.

Induction of persistent $\mathrm{T}$ cell anergy is a unique treatment result, achieved by combined treatment with LT $\beta$ R-Ig and anti-CD40L mAb. Anergic T cells from mice given combined therapy are not capable of responding to antigens after transfer into secondary recipients, even with IL-2 administration (Figure 6a). It has been reported that, upon transfer into recipient mice, 2C $\mathrm{T}$ cells undergo massive expansion by responding to $\mathrm{H}-2 \mathrm{~L}^{\mathrm{d}}$-expressing host cells, followed by a rapid decline in cell number due to activationinduced cell death (39-41). The remaining apoptosisresistant $2 \mathrm{C} \mathrm{T}$ cells, although few in number, acquire an anergic phenotype, with abrogated responses to $\mathrm{H}-2 \mathrm{~L}^{\mathrm{d}}$ antigen and decreased expression of TCR and CD8 (39-41). Our present study demonstrates that combined therapy with LT $\beta$ R-Ig and anti-CD $40 \mathrm{~L} \mathrm{mAb}$ can inhibit the induction of CTL activity in $2 \mathrm{C} \mathrm{T}$ cells, while still allowing the $\mathrm{T}$ cells to expand vigorously in the BDF1 host (Table 1). A similar process appears to occur in the B6 spleen cell transfer system, since donor cells repopulate the recipient mice (Figure 2).

$\mathrm{T}$ cells in the recipient mice exhibited an antigenexperienced phenotype with decreased CD62L expression and were unresponsive to antigen stimulation (Figure 3, Figure 5, and Figure 6), indicating that our combined therapy does not interfere with the induction of anergy. This is in remarkable contrast to the result of treatment with CTLA-4-Ig, since injection of CTLA-4-Ig during antigenic exposure often leads to $T$ cells that are unactivated, but have a functionally competent status (immunological ignorance), presumably due to simultaneous blockade of CTLA-4 and CD28 (42). It has been shown that $\mathrm{CD} 4^{+} \mathrm{CD} 25^{+}$regulatory cells contribute to the induction and maintenance of $\mathrm{T}$ cell tolerance (43), and that this mechanism is required for induction of tolerance to allogeneic antigens resulting from ex vivo blockade of CD40L or the B7-CD28/CTLA-4 pathway (44). Transfer of purified $2 \mathrm{C} \mathrm{CD8}^{+} \mathrm{T}$ cells from tolerant mice into secondary recipients carrying $\mathrm{H}-2 \mathrm{~L}^{\mathrm{d}}$ antigen did not lead to activation of $\mathrm{T}$ cells (data not shown), suggesting that $\mathrm{CD} 4^{+} \mathrm{CD} 25^{+} \mathrm{T}$ cells are not required for the maintenance of $\mathrm{T}$ cell anergy in this model. However, this observation does not exclude the possibility that $\mathrm{CD} 4^{+} \mathrm{CD} 25^{+} \mathrm{T}$ cells may be involved in the induction of $T$ cell anergy to allogeneic antigens in the early phase of the combined therapy.

The exact mechanisms by which our combined therapy induces persistent $\mathrm{T}$ cell anergy in vivo are currently unknown. Nevertheless, in our model, all hematopoietic cells are replaced by donor cells, whereas all somatic cells express host antigens, suggesting that nonhematopoietic cells in recipients may be involved in the maintenance of $\mathrm{T}$ cell anergy. It is pos- sible that thymic epithelial cells in tolerant mice are still functionally competent to negatively select antihost $\mathrm{T}$ cells from donors. Alternatively, constant exposure of $\mathrm{T}$ cells to peripheral somatic antigens might induce and maintain the anergy.

These mechanisms are not mutually exclusive. It is important that anergy of $\mathrm{T}$ cells appears to be specific, since the responsiveness of OVA TCR transgenic T cells remains normal when transferred into an environment lacking specific antigen (Figure 4). In addition, spleen cells from the tolerant mice did not inhibit anti-host CTL generation when cotransferred with naive $\mathrm{B} 6$ spleen cells into BDF1 mice (data not shown). Our results thus do not support mechanisms such as the production of suppressive cytokines by anergic $\mathrm{T}$ cells (45) or the generation of suppressive cells (41).

In vitro restimulation of spleen cells from the tolerant mice by allogeneic spleen cells induced low, but significant, CTL activity against host antigens (Figure $5 c$ ), a result consistent with restoration of CTL activity by inclusion of IL-2 in the cell culture (Figure $5 \mathrm{~d}$ ). Although IL-2 appears to reverse T cell anergy in various $T$ cell culture systems, its effect in the regulation of $\mathrm{T}$ cell anergy in vivo is yet to be established. Dallman and colleagues showed that administration of recombinant IL-2 prevented development of tolerance of a renal allograft (46). However, several studies have demonstrated that the same approach was not effective in restoration of allogeneic CTL activity (25), a result similar to the results we present here (Figure 6a). Infusion of LPS, a potent inflammatory mediator, into the mice that were infused with anergic $T$ cells also did not break tolerance in our model (data not shown), suggesting that a mechanism that operates in an in vitro system is not available in vivo. Taken together, our results indicate that combined treatment with LT $\beta$ R-Ig and anti-CD40L mAb can prevent lethal GVHD by inducing $T$ cell anergy in a mouse model and thus might represent a practical approach for translating costimulatory therapy of GVHD into clinical application.

\section{Acknowledgments}

This work was supported in part by grants from the American Cancer Society (RPG-00-226), NIH (CA-79915, CA-85721, AI-34495, AI-35225, and HL-56067), the National Natural Science Foundation of China, and the Mayo Foundation. Koji Tamada is a recipient of the US Army Breast Cancer Research Program postdoctoral fellowship. We thank K. Jensen for editing the manuscript.

1. Vallera, D.A., and Blazar, B.R. 1989. T cell depletion for graft-versus-hostdisease prophylaxis. A perspective on engraftment in mice and humans. Transplantation. 47:751-760.

2. Lenschow, D.J., Walunas, T.L., and Bluestone, J.A. 1996. CD28/B7 system of T cell costimulation. Annu. Rev. Immunol. 14:233-258.

3. Guinan, E.C., et al. 1999. Transplantation of anergic histoincompatible bone marrow allografts. N. Engl. J. Med. 340:1704-1714.

4. Blazar, B.R., Taylor, P.A., Linsley, P.S., and Vallera, D.A. 1994. In vivo blockade of CD28/CTLA4: B7/BB1 interaction with CTLA4-Ig reduces lethal murine graft-versus-host disease across the major histocompatibility complex barrier in mice. Blood. 83:3815-3825. 
5. Blazar, B.R., et al. 1996. Infusion of anti-B7.1 (CD80) and anti-B7.2 (CD86) monoclonal antibodies inhibits murine graft-versus-host disease lethality in part via direct effects on CD4+ and CD8+ T cells. J. Immunol. 157:3250-3259.

6. Durie, F.H., et al. 1994. Antibody to the ligand of CD40, gp39, blocks the occurrence of the acute and chronic forms of graft-vs-host disease. J. Clin. Invest. 94:1333-1338.

7. Blazar, B.R., et al. 2001. Ligation of 4-1BB (CDw137) regulates graft-versus-host disease, graft-versus-leukemia, and graft rejection in allogeneic bone marrow transplant recipients. J. Immunol. 166:3174-3183.

8. Tsukada, N., et al. 2000. Blockade of CD134 (OX40)-CD134L interaction ameliorates lethal acute graft-versus-host disease in a murine model of allogeneic bone marrow transplantation. Blood. 95:2434-2439.

9. Tamada, K., et al. 2000. Modulation of T-cell-mediated immunity in tumor and graft-versus-host disease models through the LIGHT costimulatory pathway. Nat. Med. 6:283-289.

10. Tamada, K., et al. 2000. LIGHT, a TNF-like molecule, costimulates T cell proliferation and is required for dendritic cell-mediated allogeneic $\mathrm{T}$ cell response. J. Immunol. 164:4105-4110.

11. Mauri, D.N., et al. 1998. LIGHT, a new member of the TNF superfamily, and lymphotoxin alpha are ligands for herpesvirus entry mediator. Immunity. 8:21-30.

12. Yu, K.Y., et al. 1999. A newly identified member of tumor necrosis factor receptor superfamily (TR6) suppresses LIGHT-mediated apoptosis. J. Biol. Chem. 274:13733-13736.

13. Browning, J.L., et al. 1997. Characterization of lymphotoxin-alpha beta complexes on the surface of mouse lymphocytes. J. Immunol. 159:3288-3298.

14. Pitti, R.M., et al. 1998. Genomic amplification of a decoy receptor for Fas ligand in lung and colon cancer. Nature. 396:699-703.

15. Harrop, J.A., et al. 1998. Antibodies to TR2 (herpesvirus entry mediator), a new member of the TNF receptor superfamily, block T cell proliferation, expression of activation markers, and production of cytokines. J. Immunol. 161:1786-1794.

16. Noelle, R. 1996. CD40 and its ligand in host defense. Immunity. 4:415-419.

17. Grewal, I.S., and Fravell, R.A. 1998. CD40 and CD154 in cell-mediated immunity. Annu. Rev. Immunol. 16:111-135.

18. Mackey, M.F., Barth, R.J., Jr., and Noelle, R.J. 1998. The role of CD40/CD154 interactions in the priming, differentiation, and effector function of helper and cytotoxic T cells. J. Leukoc. Biol. 63:418-428.

19. Ridge, J.P., Di Rosa, F., and Matzinger, P. 1998. A conditioned dendritic cell can be a temporal bridge between a CD4+ T-helper and a T-killer cell. Nature. 393:474-478

20. Larsen, C.P., et al. 1996. Long-term acceptance of skin and cardiac allografts after blocking CD40 and CD28 pathways. Nature. 381:434-438.

21. Durie, F.H., et al. 1993. Prevention of collagen-induced arthritis with an antibody to gp39, the ligand for CD40. Science. 261:1328-1330.

22. Blazar, B.R., et al. 1997. Blockade of CD40 ligand-CD40 interaction impairs CD4+ T cell-mediated alloreactivity by inhibiting mature donor $\mathrm{T}$ cell expansion and function after bone marrow transplantation. J. Immunol. 158:29-39.

23. Buhlmann, J.E., et al. 1999. Cutting edge: sustained expansion of CD8+ $\mathrm{T}$ cells requires CD154 expression by Th cells in acute graft versus host disease. J. Immunol. 162:4373-4376.

24. Saito, K., et al. 1998. Involvement of CD40 ligand-CD40 and CTLA4-B7 pathways in murine acute graft-versus-host disease induced by allogeneic T cells lacking CD28. J. Immunol. 160:4225-4231.

25. Blazar, B.R., Taylor, P.A., Noelle, R.J., and Vallera, D.A. 1998. CD4+ T cells tolerized ex vivo to host alloantigen by anti-CD40 ligand (CD40L:CD154) antibody lose their graft-versus-host disease lethality capacity but retain nominal antigen responses. J. Clin. Invest. 102:473-482.

26. Noelle, R.J., et al. 1992. A 39-kDa protein on activated helper T cells binds CD40 and transduces the signal for cognate activation of B cells. Proc. Natl. Acad. Sci. USA. 89:6550-6554.

27. Sykulev, Y., et al. 1994. High-affinity reactions between antigen-specific T-cell receptors and peptides associated with allogeneic and syngeneic major histocompatibility complex class I proteins. Proc. Natl. Acad. Sci. USA. 91:11487-11491.

28. Chen, L., et al. 1992. Costimulation of antitumor immunity by the B7 counterreceptor for the Tlymphocyte molecules CD28 and CTLA-4. Cell. 71:1093-1102.

29. Sprent, J., and Tough, D.F. 1994. Lymphocyte life-span and memory. Science. 265:1395-1400.

30. Hogquist, K.A., et al. 1994. T cell receptor antagonist peptides induce positive selection. Cell. 76:17-27.

31. Miller, J.F., and Morahan, G. 1992. Peripheral T cell tolerance. Annu. Rev. Immunol. 10:51-69.

32. Sprent, J., Schaefer, M., Lo, D., and Korngold, R. 1986. Properties of purified $\mathrm{T}$ cell subsets. II. In vivo responses to class I vs. class II H-2 differences. J. Exp. Med. 163:998-1011.

33. Korngold, R., and Sprent, J. 1987. Variable capacity of L3T4+ T cells to cause lethal graft-versus-host disease across minor histocompatibility barriers in mice. J. Exp. Med. 165:1552-1564.

34. Korngold, R. 1992. Lethal graft-versus-host disease in mice directed to multiple minor histocompatibility antigens: features of CD8+ and CD4+ T cell responses. Bone Marrow Transplant. 9:355-364.

35. Blazar, B.R., Taylor, P.A., Panoskaltsis-Mortari, A., Sharpe, A.H., and Vallera, D.A. 1999. Opposing roles of CD28:B7 and CTLA-4:B7 pathways in regulating in vivo alloresponses in murine recipients of MHC disparate T cells. J. Immunol. 162:6368-6377.

36. Futterer, A., Mink, K., Luz, A., Kosco-Vilbois, M.H., and Pfeffer, K. 1998. The lymphotoxin beta receptor controls organogenesis and affinity maturation in peripheral lymphoid tissues. Immunity. 9:59-70.

37. Mackay, F., and Browning, J.L. 1998. Turning off follicular dendritic cells. Nature. 395:26-27.

38. Degli-Esposti, M.A., et al. 1997. Activation of the lymphotoxin beta receptor by cross-linking induces chemokine production and growth arrest in A375 melanoma cells. J. Immunol. 158:1756-1762.

39. Yu, X.Z., Bidwell, S., Martin, P.J., and Anasetti, C. 1999. Visualization, fate, and pathogenicity of antigen-specific CD8+ T cells in the graft-versus-host reaction. J. Immunol. 163:4780-4787.

40. Dey, B., et al. 1999. The fate of donor T-cell receptor transgenic T cells with known host antigen specificity in a graft-versus-host disease model. Transplantation. 68:141-149.

41. Zhang, L., Miller, R.G., and Zhang, J. 1996. Characterization of apoptosis-resistant antigen-specific T cells in vivo. J. Exp. Med. 183:2065-2073.

42. Perez, V.L., et al. 1997. Induction of peripheral T cell tolerance in vivo requires CTLA-4 engagement. Immunity. 6:411-417.

43. Asano, M., Toda, M., Sakaguchi, N., and Sakaguchi, S. 1996. Autoimmune disease as a consequence of developmental abnormality of a $\mathrm{T}$ cell subpopulation. J. Exp. Med. 184:387-396.

44. Taylor, P.A., Noelle, R.J., and Blazar, B.R. 2001. CD4+CD25+ immune regulatory cells are required for induction of tolerance to alloantigen via costimulatory blockade. J. Exp. Med. 193:1311-1318.

45. Tanchot, C., et al. 1998. Modifications of CD8+ T cell function during in vivo memory or tolerance induction. Immunity. 8:581-590.

46. Dallman, M.J., Shiho, O., Page, T.H., Wood, K.J., and Morris, P.J. 1991. Peripheral tolerance to alloantigen results from altered regulation of the interleukin 2 pathway. J. Exp. Med. 173:79-87. 